\title{
Biodiversity and Structure of Woody Plants of Sahelian Rangelands of Baban Rafi, Niger
}

\author{
Soumana Idrissa ${ }^{1}$, Rabiou Habou ${ }^{2}$, Issaharou Matchi Issiaka ${ }^{2}$, Ali Mahamane ${ }^{3} \&$ Saadou Mahamane $^{3}$ \\ ${ }^{1}$ Institut National de la Recherche Agronomique du Niger, Niger \\ ${ }^{2}$ Université de Diffa, Niger \\ ${ }^{3}$ Université de Niamey, Niger \\ Correspondance: Soumana Idrissa, Département des Productions Animales, Institut National de la Recherche \\ Agronomique du Niger, BP: 78Niamey-Niger. Tel: 227-9689-3908. E-mail: smaiga15@yahoo.fr
}

Received: June 23, 2017

Accepted: July 3, 2017

Online Published: July 19, 2017

doi:10.5539/ijb.v9n4p1

URL: https://doi.org/10.5539/ijb.v9n4p1

\begin{abstract}
The present study investigates the importance of harvesting regimes and natural disturbances on the diversity, the population structure and the regeneration trends of the woody plant species of Sahelian rangelands and their implication for sustainable browsing management. Woody plants data was collected in 42 plots established in the interval of $500 \mathrm{~m}$, along transects distant of $500 \mathrm{~m}$, in the direction South-west and North-east of the study area. In each plot, height and diameter at breast height of each individual mature tree and shrub (diameter $<4 \mathrm{~cm}$ ), and the number of seedlings (diameter $>4 \mathrm{~cm}$ ) were recorded. A total number of 21 plants species were recorded, with low values of the Shannon-Weaver $\left(\mathrm{H}^{\prime}\right)$ index and the evenness of Piélou (E) indicating very low diversity of rangelands. Analysis of size classes distribution of diameters and heights of the whole vegetation and the three dominants species revealed high density of juveniles, relating to stable populations. The juvenile plants represented more than 80 of the vegetation with diameters and heights respectively lower than $6 \mathrm{~cm}$ and $2.5 \mathrm{~m}$, indicating shrubby vegetation. Combretum micranthum, Guiera senegalensis and Combretum nigricans which have the highest values of IVI, have also the greatest rates of seedling and vegetative propagation densities. Stable populations with strong capacity of regeneration under harsh area and high human pression such as logging and grazing can be related ecological success. Management practices that promote plantations or managing natural regeneration of such species can facilitate fast secondary succession towards desirable condition.
\end{abstract}

Keywords: woody plants, size classes distribution, density, regeneration

\section{Introduction}

Woody as well as herbaceous plants provide various services of great socioeconomical and ecological importance. Beyond their critical role in the Earth functioning system, plants contribute to human welfare either directly or indirectly, and therefore represent part of the total economic value of the planet (Costanza et al., 1997; MEA, 2005). Livestock grazing is one of the main disturbance factors that affect plants composition and generally biodiversity (Biondini et al., 1998; Cingolani et al., 2005). In the dry systems such as the Sahel, wherein most of the consuming feed by livestock is supplied by rangelands, loss of biodiversity towards unpalatable species is critical for sustainable livestock production. Hence, sustainable conservation and utilization plans based on sound scientific knowledge are needed to be adopted to avoid further degradation of rangelands.

Woody plants such as trees and shrubs are important component of Sahelian vegetation as well as plants communities. They are present almost everywhere in the Sahel, with a density of 100 to 400 individuals per hectare (Le Houerou, 1980a). Source of fodder with relatively higher nutrients and minerals contents, woody vegetation also provides timber, fuelwood, etc., as well as ecosystem processes regulation like soil and site stability, nutrient cycling and water infiltration (Le Houerou, 1980b; von Maydell 1990; Arbonnier, 2002). Despite these socioeconomical and ecological importance, sahelian vegetation particularly woody plants are considerably affected by human activities in many ways, principally agriculture, livestock grazing and logging (Hiérnaux \& LeHouérou, 2006), exacerbated by the current climatic trends (Ozer, 2010; Nicholson and Grist, 2001). Currently, sahelian vegetation are among the most threatened plants with a relatively very low density and poorly natural regeneration of most the main emblematic plants species such as Pterocarpus erinaceus (Rabiou et al., 2005), 
Prosopis africana (Abdou et al., 2016), Combretum nigricans (Amani, 2016), etc. Species conservation in this context is a critical issue due to the lack of sufficient information on the conservation status of a large number of species. Study of rejuvenation status of species using analysis of size class distribution method can provide valuable information about the impact of disturbances on vegetation changes (Lykke, 1998). In this study, we investigate the importance of harvesting regimes and natural disturbances on the population structure and the regeneration trends of the woody plant species of Sahelian rangelands and their implication for sustainable browsing management.

\section{Materials and Methods}

\subsection{Description}

The study was conducted in the Central-south of Niger, at the Sahelo-soudanian bioclimatic region (Saadou, 1990). The study area extensively grazed by livestock is close to the protected forest of Baban Rafi. It has also experienced high immediate local community activities such as wood harvesting to supply urban areas and rangelands conversion to cropland. These have made the system highly degraded with locally high barren surface. The climate of the area is tropical arid with a mean annual of rainfall of $481 \mathrm{~mm}$ (data from 1985 to 2016, Meteorological data from Baban rafi), received from June to September with a peak in August. The mean annual of temperature is $33^{\circ} \mathrm{C}$, with the lower values of $24.8^{\circ} \mathrm{C}$ and $22.5^{\circ} \mathrm{C}$ recorded respectively in December and January and highest values of $32,9^{\circ} \mathrm{C}$ and $28,8^{\circ} \mathrm{C}$, recorded in May and October. The soils in the study area represent two geomorphological units: the lateritic plateaus formed by the deposit of the Continental Hamadien, and the dry valleys, sandy terraces and fixed dunes made by the Quaternary sands (Mahamane et al., 2009). The principal tree species in the study area are Sclerocarya birrea (A. Rich.) Hochst., Anogeissus leiocarpus (DC.) Guill. et Perr., Combretum micranthum G.Don., Cassia singueana Del., Boscia salicifolia Oliv. and Boscia senegalensis (Pers.) Lam. Ex Poir. on the lateritic plateaus, and Prosopis africana (Guill. Et Perr.) Taub., Lannea microcarpa Engl. et K. Krauze, Adansonia digitate L., Bauhinia rufescens Lam., Ziziphus spina-christi (L.) Desf., Piliostigma reticulatum (DC.) Hochst., Hyphaene thebaica (L.) Mart., Annona senegalensis Pers., Faidherbia albida (Del.) A. Chev., Catunaregam nilotica (Stapf) Tiruvengadum and Albizia chevalieri Harms. on the sandy terraces, fixed dunes and dry valleys (Saadou, 1990). Most of these woody species are locally endangered.

\subsection{Methods of Data Collection}

Trees and shrubs characteristics have been measured in 42 rectangular plots of $20 \mathrm{~m}$ x $50 \mathrm{~m}\left(1000 \mathrm{~m}^{2}\right)$. In each pastureland, the plots have been laid in the interval of $500 \mathrm{~m}$, along transects distant of $500 \mathrm{~m}$, established in the direction South-west and North-east (Figure 2). In each plot, Height and diameter at breast height of each individual mature tree and shrub (diameter $<4 \mathrm{~cm}$ ), and the number of seedlings (diameter $<4 \mathrm{~cm}$ ) were recorded. Height of each individual has been measured with graduated stake. For each mature individual plant, circumference at breast height was measured with tailor's tape. Nomenclature adopted for plants is that of Lebrun and Stork (1991-2015). The list of the specie families recorded in this study was arranged according to the Linear Angiosperm Phylogeny Group (LAPG) IV (APG, 2016).

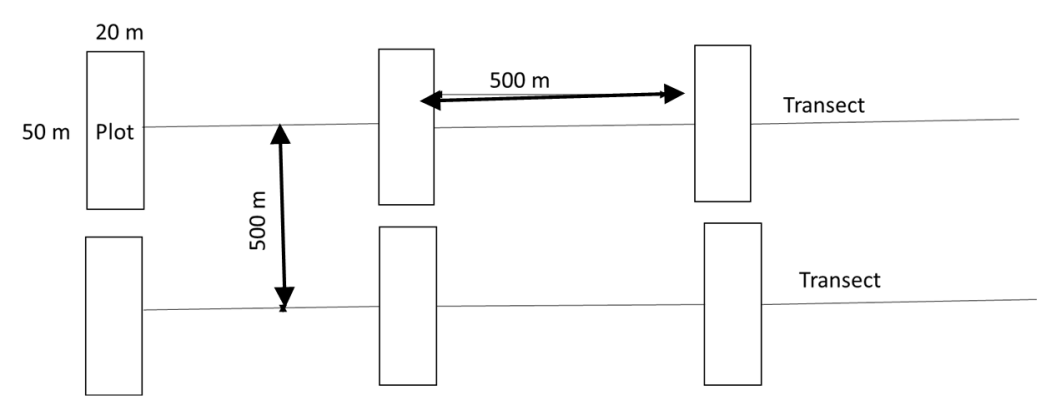

Figure 2. Lay out and sizes of sample plots and transects in the study area

\subsection{Methods of Data Analysis}

First, the densities (N) as well as the basal area of each taxon were assessed. The density (N) of each taxa is assessed as the number of the taxa per unit area: 


$$
\mathrm{N}=\frac{\mathrm{n}}{\mathrm{s}}
$$

With $\mathrm{n}$ is the total number of individual plants of the species in the area and $\mathrm{s}$ the surface of the area in ha. Then, we computed the basal areal $(\mathrm{G})$ of the whole study area and the Importance of each taxon on the rangelands are evaluated following calculating of the importance value index (IVI) (Curtis \& Macintosh, 1951). G of the whole study area is computed by:

$$
G=\frac{\pi}{4 s} \sum_{i=1}^{n} \mathrm{di}^{2}
$$

With $\mathrm{d}$ is the trunk diameter $(\mathrm{cm})$ of the tree $\mathrm{i}$ at breast height and $\mathrm{S}$ the area of the study plot (ha) (Van Laar \& Akca, 2007); and the IVI of each species is computed following this formula:

$$
\text { IVI }(\%)=\text { relative density }+ \text { relative frequency }+ \text { relative basal area, }
$$

with the relative basal area of one species is the quotient of its basal area per total basal area of total species, the relative density of a species is the ratio between its absolute density and total absolute densities of all species expressed in percentage. The relative frequency of a species is the ratio between its specific frequency and the total specific frequencies of all the species expressed in percentage. The alpha diversity of the wood vegetation is assessed following Shannon-Weaver (1949) index (H'), evenness (E) of Piélou (1966) as well as floristic richness (i.e. number of species in a sample unit; R). $\mathrm{H}^{\prime}$ is calculated using this formula:

$$
H^{\prime}=\sum_{i=1}^{s} P i \log 2 P i,
$$

With pi between 0 and 1 is the relative proportion of frequency of species $\mathrm{i}$; $\mathrm{Pi}=\mathrm{ni} / \Sigma \mathrm{ni}$, with $\mathrm{n}=$ average frequency of specie i and $\Sigma \mathrm{ni}=$ total frequency of all species. $E$ the degree of diversity of a given site compared with the maximum possible:

$$
E=\frac{H^{\prime}}{H \max } ; \mathrm{H}^{\prime} \mathrm{Hmax}=\log _{2} \mathrm{~S},
$$

With Hmax is the maximum theoretical index, $\mathrm{H}^{\prime}$ is the Shannon-Weaver (1949) index and $\mathrm{S}$ is the number of species recorded in a given site. Finally, the parameters of the Weibull distribution were estimated from diameter and height data by using Minitab 14 (Dytham, 2011). The Weibull distribution with three parameters ( $a, b$ and c), characterized by flexibility of use and variability, enabled the improved adjustment of distribution curves. The probability density function, $\mathrm{f}(\mathrm{x})$ (Rondeux, 1999), was calculated by computed the following formula:

$$
f(x)=\frac{c}{b}\left(\frac{x-a}{b}\right)^{c-1} \exp \left[-\left(\frac{x-a}{b}\right)^{c}\right],
$$

Where $\mathrm{x}$ is the diameter or the height of the trees and $\mathrm{f}(\mathrm{x})$ the probability density value, $\mathrm{a}$ is the position parameter, $\mathrm{b}$ is the scale or size parameter and $\mathrm{c}$ is the shape parameter related to the observed structure.

\section{Results}

\subsection{Woody Plants Diversity and Importance}

A total number of 21 native woody plants species have been recorded in 42 plots of the rangelands of Baban Rafi. Alpha diversity analysis based on the Shannon-Weaver ( $\left.\mathrm{H}^{\prime}\right)$ index and the evenness of Piélou (E) revealed very low diversity of the sahelian rangelands woody plants with respectively 1.76 and 0.39 of H' and E. The low amount of $\mathrm{E}$ indicates the dominancy of few numbers of dominant species. The few common and widespread species confirmed by the IVI index and that have the highest frequencies, dominances and densities are Combretum micranthum, Guiera senegalensis and Combretum nigricans with respectively 124.60, 103.80 and 66,98 of IVI (table 1). C. micranthum which has the greatest IVI index, has also the highest amounts of basal and relative dominances, and the lowest relative frequency. It is followed by C. nigricans for the basal dominancy, which has the intermediate value of relative frequency and the lowest relative dominancy. Finally, C. micranthum is followed by G. senegalensis for the value of relative dominancy, which has the highest value of relative frequency and the lowest value of basal dominancy. However, these rangelands have three Combretaceae shrubs as dominant plants species. The other species are low represented in the study area with a very low IVI index, some of these species such as Prosopis africana and Sclerocarya birrea are threatened in these rangelands. 
Table 1. Importance value index of the twelve most dominant species of the study area

\begin{tabular}{|c|c|c|c|c|c|}
\hline Plant species & Family & Relative Basal area (\%) & Relative frequency (\%) & Relative density (\%) & IVI \\
\hline Acacia erythrocalyx Brenan. & Fabaceae & 0,31 & 0,20 & 0,26 & 0,77 \\
\hline Boscia angustifolia A.Rich. & Capparaceae & 0,02 & 0,25 & 0,00 & 0,27 \\
\hline Boscia senegalensis (Pers.) Lam. Ex Poir. & Capparaceae & 0,43 & 1,07 & 0,29 & 1,79 \\
\hline Combretum glutinosum Perr ex DC & Combretaceae & 0,16 & 0,05 & 0,05 & 0,25 \\
\hline Combretum micranthum G.Don. & Combretaceae & 54,77 & 22,82 & 47,02 & 124,60 \\
\hline Combretum nigricans var elliotii (Engl. Ex Diels) Aubrev. & Combretaceae & 30,08 & 24,16 & 12,75 & 66,98 \\
\hline Feretia apodanthera Del. & Rubiaceae & 0,02 & 0,09 & 0,00 & 0,11 \\
\hline Grewia flavescens Juss. & Malvaceae & 0,08 & 0,34 & 0,03 & 0,45 \\
\hline Guiera senegalensis J.G.Gmel. & Combreataceae & 13,83 & 50,75 & 39,22 & 103,80 \\
\hline Bombax costatum Pellegr. & Bombacaceae & 0,04 & 0,02 & 0,00 & 0,06 \\
\hline Piliostigma reticulatum (DC.) Hochst. & Fabaceae & 0,25 & 0,20 & 0,37 & 0,83 \\
\hline Sclerocarya birrea (A.Rich.) Hochst. & Anacardiaceae & 0,02 & 0,02 & 0,01 & 0,05 \\
\hline
\end{tabular}

\subsection{Structure of the Whole Rangelands Vegetation}

The DBH classes distribution of the whole rangelands plants species exhibited at the lowest class $(4 \mathrm{~cm}<\mathrm{DBH}<6 \mathrm{~cm})$, high density of plants (Figure), this class of diameter represented $81 \%$ of the whole vegetation. The density of the other diameter classes decreases with increase of the diameter size. Furthermore, plants with diameter range from $8 \mathrm{~cm}$ to $10 \mathrm{~cm}$ become very scarce and those with diameter superior to $10 \mathrm{~cm}$ are completely missing in the ranges. The distribution of these diameter fit the theoretical distribution of Weibull with the shape parameter $\mathrm{c}=1.596$ ranged between 1 and 3.6 which indicates vegetation with predominance of young individuals. Moreover, distribution of heights classes indicates also highly predominance of young individual plants, with heights lesser than $2.5 \mathrm{~m}$, these plantlets represented $86 \%$ of the whole vegetation. The distribution of Weibull indicates a shape parameter of $\mathrm{c}=2.625$ and confirmed the results from diameter classes distribution (Figure 2).
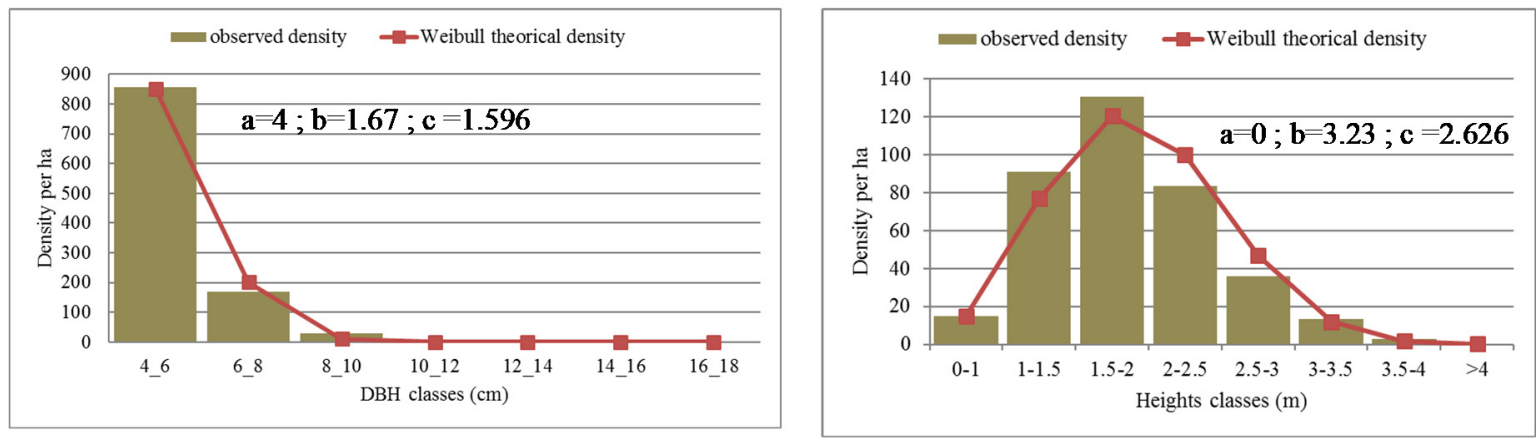

Figure 2. Diameter and heights class distribution of the vegetation of the whole study area

According to IVI index analysis, three species such as Combretum micranthum, Guiera senegalensis and Combretum nigricans have been identified as dominant species of the rangelands. The observed distribution of the three shrubs diameter classes structure as well as heights classes structure fit well with shape parametter of Weibull distribution.The DBH classes distribution for the three species reveals c shape parameter of Weibull distribution ranged between 1 and 3.6 that indicates vegetation with predominance of young individuals as well as the DBH classes distribution for the whole rangelands excepted Combretum nigricans DBH classes distribution which has a "inversed" J shape with a shape parameter $\mathrm{c}=0.7554$. These two models of distribution similarly indicate populations with dominance of juvenile plants. This results is confirmed by the heigt classes distribution of the three plants species which have all their shape parameter of weibull ranged from 1 to 3.6. The more common heights classes of the three populations of the rangelands consisted of plants ranging from $1 \mathrm{~m}$ to $3 \mathrm{~m}$ in tall, these heights classes are more than $80 \%$ of the total plants occurred in the rangelands. 

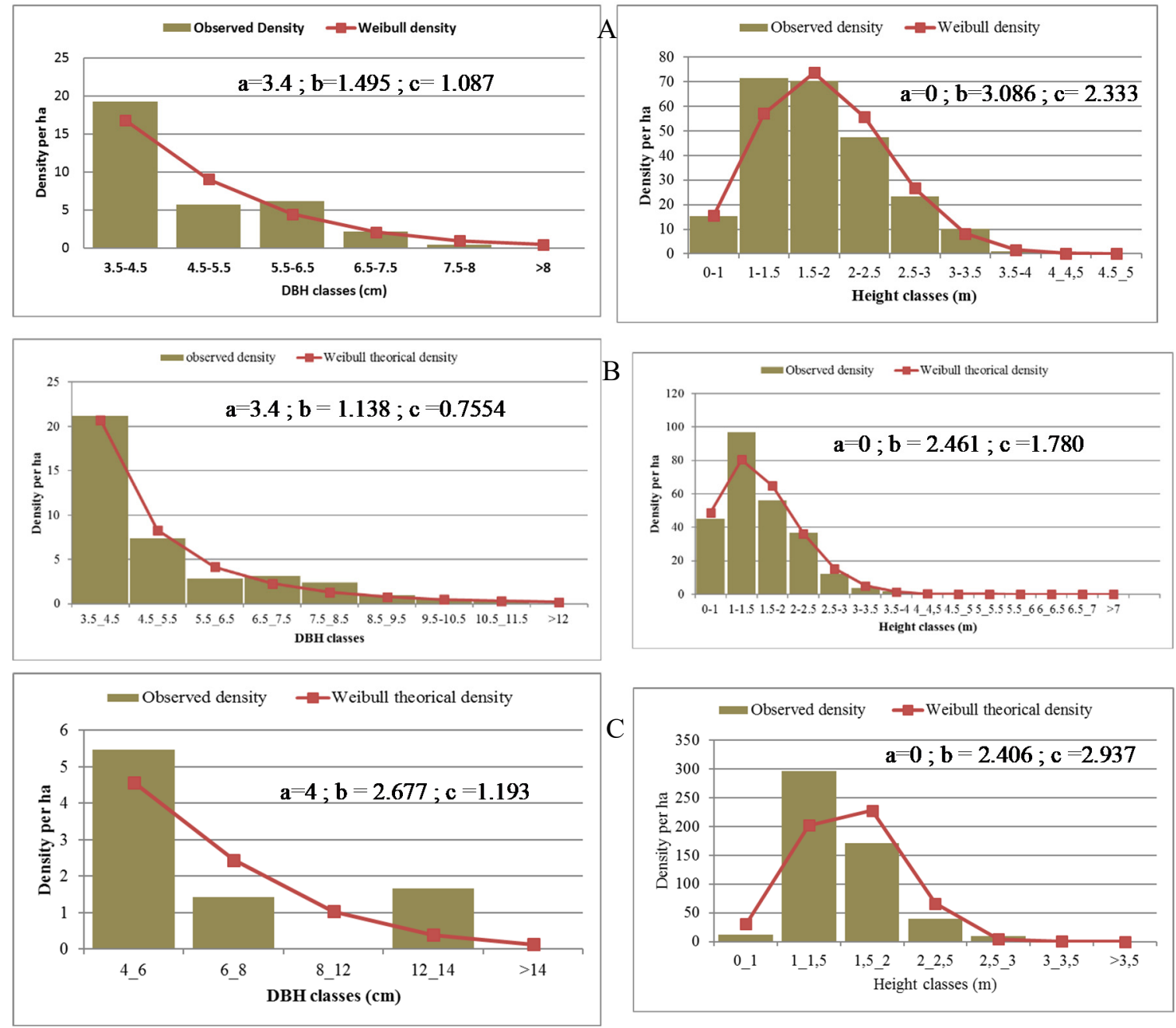

Figure 3. Diameter and height size classes of the three dominants species in study area $(\mathrm{A}=$ Combretum micranthum, $\mathrm{B}=$ Combretum nigricans and $\mathrm{C}=$ Guiera senegalensis $)$

\subsection{Recruitment of Woody Plants Species}

Two mechanisms of wood plants regeneration have been identified in the rangelands which include seedling and vegetative propagation (layering and root sucker). The three important species according to IVI index analysis have also significant capacity of recruitment with high densities of seedling and vegetation propagation. Guiera senegalensis have the highest density of seedling with $4290.29 \pm 271.34$ plants/ha, followed by Combretum nigricans (86.67 \pm 89.38 plants/ha) and Combretum micranthum (78.33 \pm 55.34 plants/ha). In contrary, Combretum micranthum which have the second highest density of seedling, have the strongest density of vegetative propagation ( $36.0 \pm 29.4 \mathrm{plants} / \mathrm{ha})$, followed by Guiera senegalensis $(27.2 \pm 23.1 \mathrm{plants} / \mathrm{ha}$ ) which have the highest

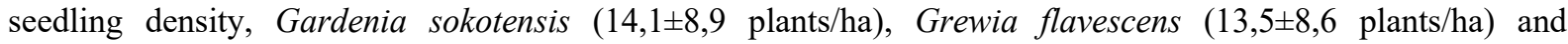
Combretum nigricans $(12,6 \pm 10,9$ plants/ha) which has the third density of seedling. Most of the species have strong rate of regeneration (>50\%) excepted Prosopis africana and Sclerocarya birrea which have the lowest recruitment capacity. 
Table 2. Seedling and vegetative propagation densities and regeneration rates of the woody plants species

\begin{tabular}{|c|c|c|c|c|c|}
\hline \multirow[t]{2}{*}{ Species } & \multicolumn{2}{|c|}{$\begin{array}{c}\text { Seedling density } \\
\left(\text { Number of seedling ha }{ }^{-1}\right)\end{array}$} & \multicolumn{2}{|c|}{$\begin{array}{l}\text { Vegetative propagation density } \\
\left(\text { Number of regeneration } \mathrm{ha}^{-1}\right)\end{array}$} & \multirow[t]{2}{*}{ Regeneration rate (\%) } \\
\hline & Average & Standard deviation & Average & Standard deviation & \\
\hline Acacia ataxacantha & $0,95^{\mathrm{d}}$ & 3,70 & $5,5^{\mathrm{d}}$ & 2,1 & 100,00 \\
\hline Acacia erythrocalyx & $0,24^{\mathrm{d}}$ & 1,54 & $2,2^{\mathrm{d}}$ & 1,7 & 55,56 \\
\hline Asparagus africanus & $2,14^{\mathrm{d}}$ & 4,70 & $5,9^{\mathrm{d}}$ & 3,2 & 100,00 \\
\hline Boscia angustifolia & $0,95^{\mathrm{d}}$ & 4,31 & $2,5^{\mathrm{d}}$ & 2,4 & 100,00 \\
\hline Boscia salicifolia & $2,86^{\mathrm{d}}$ & 5,54 & $1,4^{\mathrm{d}}$ & 1,0 & 92,86 \\
\hline Boscia senegalensis & $8,57^{\mathrm{c}}$ & 13,17 & $7,9^{\mathrm{c}}$ & 9,8 & 94,44 \\
\hline Combretum micranthum & $78,33^{\mathrm{b}}$ & 55,34 & $36,0^{\mathrm{a}}$ & 29,4 & 91,68 \\
\hline Combretum nigricans & $86,67^{b}$ & 89,38 & $12,6^{\mathrm{b}}$ & 10,9 & 89,34 \\
\hline Sterculia setigera & $0,24^{\mathrm{d}}$ & 1,54 & $0,0^{\mathrm{d}}$ & 0,0 & 100,00 \\
\hline Dichrostachys cinerea & $0,24^{\mathrm{d}}$ & 1,54 & $9,0^{\mathrm{d}}$ & 9,0 & 100,00 \\
\hline Feretia apodanthara & $0,71^{\mathrm{d}}$ & 2,61 & $8,7^{\mathrm{c}}$ & 6,7 & 100,00 \\
\hline Gardenia sokotensis & $1,90^{\mathrm{d}}$ & 6,71 & $14,1^{\mathrm{b}}$ & 8,9 & 100,00 \\
\hline Grewia flavescens & $2,86^{\mathrm{d}}$ & 9,18 & $13,5^{\mathrm{b}}$ & 8,6 & 98,07 \\
\hline Guiera senegalensis & $429,29^{\mathrm{a}}$ & 271,34 & $27,2^{\mathrm{a}}$ & 23,1 & 98,93 \\
\hline Gymnema Silvestre & $0,48^{\mathrm{d}}$ & 2,16 & $10,0^{\mathrm{c}}$ & 2,8 & 100,00 \\
\hline Maerua angolensis & $1,43^{\mathrm{d}}$ & 3,54 & $4,3^{\mathrm{d}}$ & 4,8 & 100,00 \\
\hline Piliostigma reticulatum & $0,95^{\mathrm{d}}$ & 6,17 & $9,9^{\mathrm{c}}$ & 7,0 & 88,46 \\
\hline Prosopis Africana & $0,00^{\mathrm{d}}$ & 0,00 & $1,0^{\mathrm{d}}$ & 1,0 & 0,00 \\
\hline Sclerocaria birrea & $0,00^{\mathrm{d}}$ & 0,00 & $1,0^{\mathrm{d}}$ & 1,0 & 0,00 \\
\hline P-value & & $<0,001$ & & $<0,001$ & - \\
\hline
\end{tabular}

\section{Discussion}

\subsection{Plants Composition and Diversity}

The rangelands under this study is relatively poorly diversified with a total number of 21 woody plants species in accordance with vegetation inventory by Ndiaye et al., (2010) at Ranerou but lower than Ngom et al. (2013) in the Ferlo and Baggian et al. (2014) in the agroforestry park of Niger. Among these species, Combretum micranthum, Guiera senegalensis and Combretum nigricans belonging to the family of Combretaceae appear clearly as the most common and widespread species with a very high importance values. These species are among the most importance species recorded in the sahelian region by inventories (Ngom et al., 2013; Manzo et al., 2017: Baggian et al. (2014). The dominance of those three species explains the low diversity and evenness of the rangelands. Furthermore, these species are widespread in the sahelian bioclimatic region (Arbonnier, 2004), they are mainly associated to the tiger bushes (Müller, 2013; Saley, 2012) generally harvested for firewood to supply urban areas (Montagne \& Housseini, 1997; Montagne, 1997). Logging may be their main threat in the Western Niger due to the high quality of their firewood. The other species, in a total of 18 species, are scattered with a very low value of IVI index. These scattered species include Acacia ataxacantha, Acacia erythrocalyx, Asparagus africanus, Boscia angustifolia, Boscia salicifolia, Boscia senegalensis, Sterculia setigera, Dichrostachys cinerea Feretia apodanthara, Gardenia sokotensis, Grewia flavescens, Gymnema silvestre, Maerua angolensis, Piliostigma reticulatum, Prosopis africana and Sclerocaria birrea. Although these species are scarce in the rangelands, they are well represented in the nearby protected forest of Baban Rafi, hence their lowly IVI index in the study area could be explained by the regime of exploitation mainly due to grazing because of their great palatability and the quality of their timber or wood (Bognounou et al., 2010). According to the local communities, the main human pressions in the area are grazing and browsing by herbivore, logging, rangeland conversion to croplands, etc. which in results affect plantlets growing, establishment and distribution. The species which have the lowest IVI, have also the lowest regeneration densities with low number of seedling, layering and root sucker excepted Gardenia sokotensis, Grewia flavescens, Gymnema Silvestre, Piliostigma reticulatum that have relatively strong vegetative propagation rates. Their lowest seedling density could be linked to the disappearances or the scarcity of adult plants fruiterer through harvesting and pruning for livestock feeding. These may limit seeds providing which combining with livestock browsing affect seedling establishment and density. Combretum micranthum, Guiera senegalensis and Combretum nigricans which have the highest IVI, have also the highest density of regeneration despite their great harvesting to supply firewood. These species are lowly used for livestock feeding. The high importance of these species in the rangelands could be linked to their strong capacity of regeneration by seeds and 
vegetation propagation and their lower pruned or browsed for livestock feeding. Strong capacity of regeneration of Combretum micranthum, Guiera senegalensis and Combretum nigricans have been notified by several studies (Charahabil et al., 2013; Ngom, 2013; Baggnian, 2014; Manzo et al., 2017). Species with great IVI and regeneration rates in harsh area like the Sahel, are indications of ecological success. Because of their ecological success in the sahelian region, these species have great potential to resist to drought and the elevation of local temperature (Savadogo et al., 2016). Management practices that promote plantations or managing natural regeneration of such species can facilitate fast secondary succession towards desirable condition.

\subsection{Dynamic of Sahelian Rangelands Woody Plants}

Globally, analysis of size classes distribution of diameter and height of the whole vegetation and each of the three dominant species reveal clearly the predominance of plantlets with total lacking of adults with height superior to 4 $\mathrm{m}$, which indicating shrubs vegetation, consistent with Müller (2013) in the tiger bush of Burkina Faso and Charahabil et al. (2013) in the soudano-sahelian region of Senegal. In arid areas, shrubby plants tend to be most abundant than trees because plants expand horizontally rather than vertically in order to provide safe microsites (Galal, 2011). Furthermore, horizontal expansion tends to increase soil capital resources such as water, soil organic matter, nutrients, etc. capturing by increasing soil surface roughness and reduce soil heats by shading. Capital resources capturing and soil surface heating reducing may augment soil biota activities and safe microsites availability. In xeric environment, these conditions are essential for vegetation recovery because, they contribute in enhancing conditions that facilitate seed germination, seedling and sapling growing and maintaining, essential for vegetation recovery. More than $90 \%$ of the whole plants have less than $8 \mathrm{~cm}$ of diameter, revealing vegetation dominated by seedling and sapling, in accordance with Charahabil et al. (2013). The predominance of young plants confirmed the high capacity of regeneration of the dominant species and the low distribution of adult plants indicates their highly exploitation. The predominance of young over the mature plants in a system have been attributed to stable population (Galal, 2011). Moreover, high abundant of juveniles is essential for a population to maintain itself (Lykke, 1998; Okiror et al., 2012). In fact, the resilience of these rangelands depends to the availability of safe microsites and capital resources capturing, favoring the self-regeneration of the plants. Overall these rangelands vegetation as well as the populations of Combretum micranthum, Guiera senegalensis and Combretum nigricans are stable communities. Adult plants even in less density in stable communities are very important for secondary succession due their high capacity to provide seeds. Overexploitation of adult plants by wood harvesting or pruning to feed livestock can limit seed availability which in term can reduce seedling establishment. Safe microsite destruction by livestock trampling due to overstocking can also restraint seed germination by increasing soil erosion through wind and run off. Thresholds that restraint seed providing and germination can explain the lowly occurrence of several plant species like Prosopis africana and Sclerocaria birrea, etc. Lack or scarce of adult plants indicates either their highly mortality or small fraction of the seedling and sapling classes usually survives to the larger tree classes (Okiror et al., 2012). Mortality of seedling or sapling or both can be linked to lack of safe microsite or small terrestrial animals as well as the highly seasonality and amount of the rainfall particularly in the Sahel where rainfall pattern is correlated with the distribution of the main common species (Agea et al. 2005; Schmidt et al., 2005). But at adult stage, woody plants health in rangelands can be affected by many biotic and abiotic factors, including natural and human-caused disturbances and variation in climates. Sustainable grazing management of sahelian rangelands may depend on many factors, including safe microsite availability to sustain seed germination, seedling and sapling growing, anthropogenic activities to control logging, rangeland conversion to crops lands, stocking rates and the future climate changes. Seemly, condition of controlling grazing intensity and limiting rangelands conversion to croplands can alleviate the negative effect of overstocking by limiting safe microsites destruction by trampling and by increasing recovery time after grazing events. On grazing lands, safe microsite availability is crucial for plants recovery (Elmarsdottir et al., 2003; Oesterheld \& Sala, 1990) as well as management strategies such as rotation, mobility, etc. that increase recovery time after grazing events (Fuhlendorf \& Engle 2001; Yeo, 2005).

\section{Conclusion and Implication for Sustainable Rangelands Management}

Finding of this study reveal clearly poorly diversified rangelands with high predominance of three shrubby species: Combretum micranthum, Guiera senegalensis and Combretum nigricans, the other woody species are scarce in the study area excepted in the nearby protected forest of Baban Rafi. The high dominant species have also the greatest regeneration rates through seeds and vegetative propagation. The high distribution of shrubby plants is favourable in increasing safe microsites. Increasing safe microsites enhance seed germination, seedling and sapling development. This condition may facilitate secondary succession which in term may improve biodiversity in which depends rangelands health. Although these species have stable and great regeneration rates, this situation can change if management practices that alleviate human pression are not adopted by local communities. These 
practices can result in preserving abundant plants species and direct secondary succession towards desirable condition.

\section{References}

Abdou, L., Morou, B., Abasse, T., \& Mahamane, A. (2016). Analysis of the structure and diversity of Prosopis africana (G. et Perr.) Taub. tree stands in the southeastern Niger. Journal of Plant Studies, 5(1), 58. https://doi.org/10.5539/jps.v5n1p58

Agea, J. G., Obua, J., Namirembe, S., Buyinza, M., \& Waiswa, D. (2005). Agroforestry potential of Acacia senegal in the rangelands of Luwero and Nakasongola districts. Uganda Journal of Agricultural Sciences, 11, 34-39.

APG. (2016). An update of the Angiosperm Phylogeny Groupclassification for the orders and families of floweringplants: APG IV. Botanical Journal of the Linnean Society, 181, 1-20.

Arbonnier, M. (2002). Arbres, arbustes et lianes des zones sèches d'Afrique de l'Ouest. Edition CIRAD, MNHN, France.

Baggnian, I., Adam, T., Adamou, M. M., Chaibou, I., \& Mahamane, A. (2014). Structure et dynamique de la végétation ligneuse juvénile issue de la régénération naturelle assistée (RNA) dans le Centre-Sud du Niger. International Journal of Biological and Chemical Sciences, 8(2), 649-665. Retrieved from http://ajol.info/index.php/ijbcs

Biondini, M. E., Patton, B. D., \& Nyren, P. E. (1998). Grazing intensity and ecosystem processes in a northern mixed-grass prairie, USA. Ecological Applications, 8(2), 469-479.

Bognounou, F., Tigabu, M., Savadogo, P., Thiombiano, A., Boussim, I. J., Oden, P. C., \& Guinko, S. (2010). Regeneration of five Combretaceae species along a latitudinal gradient in Sahelo-Sudanian zone of Burkina Faso. Annals of Forest Science, 67(3), 306. https://doi.org/10.1051/forest/2009119

Charahabil, M. M., Diallo, A., Ngom, D., Diop, B., \& Akpo, L. E. (2013). Importance des Combretaceae dans des forêts communautaires de la zone soudano-sahélienne au Sénégal. Science et changements planétaires/Sécheresse, 24(1), 39-47. https://doi.org/10.1684/sec.2012.0368

Cingolani, A. M., Noy-Meir, I., \& Díaz, S. (2005). Grazing effects on rangeland diversity: a synthesis of contemporary models. Ecological applications, 15(2), 757-773.

Costanza, R., d'Arge, R., De Groot, R., Farber, S., Grasso, M., Hannon, B., ... \& Raskin, R. G. (1997). The value of the world's ecosystem services and natural capital. nature, 387(6630), 253-260.

Dytham, C. (2011). Choosing and using statistics: a biologist's guide. John Wiley \& Sons.

Elmarsdottir, A., Aradottir, A. L., \& Trlica, M. (2003). Microsite availability and establishment of native species on degraded and reclaimed sites. Journal of Applied Ecology, 40, 815-823. http://dx.doi.org/10.1046/j.1365 -2664.2003.00848.x

Fuhlendorf, S. D., \& Engle, D. M. (2001). Restoring Heterogeneity on Rangelands: Ecosystem Management Based on Evolutionary Grazing Patterns: We propose a paradigm that enhances heterogeneity instead of homogeneity to promote biological diversity and wildlife habitat on rangelands grazed by livestock. BioScience, 51(8), 625-632.

Galal, T. M. (2011). Size structure and dynamics of some woody perennials along elevation gradient in Wadi Gimal, Red Sea coast of Egypt. Flora-Morphology, Distribution, Functional Ecology of Plants, 206(7), 638-645.

Hiernaux, P., \& Le Houérou, H. N. (2006). Les parcours du Sahel. Sécheresse, 17, 51-71.

Le Houérou, H. N. (1980b). Browse in Africa: the current state of knowledge. Papers presented at the international symposium on browse in Africa, April 8-12 1980. International Livestock Center for Africa Addis Ababa, Ethiopia.

Lebrun, J. P., \& Stork, A. L. (1991-2015). Enumération des plantes à fleurs d'Afrique tropicale et Tropical African Flowering Plants: Ecology and Distribution, vol. 1-7. Conservatoire et Jardin botaniques de la Ville de Genève.

LeHouérou, H. N. (1980a). The Rangelands of the Sahel. Journal of Range Management, 33(1), 41-46.

Lykke, A. M. (1998). Assessment of species composition change in savanna vegetation by means of woody plants' size class distributions and local information. Biodiversity and Conservation, 7(10), 1261-1275. 
Mahamane, A., Saadou, M., Bä̈naDanjimo, M., Karim, S., Bakasso, Y., Diouf, A., ... \& Arzika, T. (2009). Biodiversite végétale au Niger: Etat des connaissances actuelles. Plants diversity in Niger: state of the presentstudies. Ann. Univ. Lomé (Togo), 81-93.

Manzo, O. L., Garba, O. B., Morou, B., Karim, S., \& Mahamane, A. (2017). État de la végétation ligneuse au Sahel: Cas de Guidan Roumdji au sahel central du Niger. Journal of Animal \&Plant Sciences, 31(3), 5033-5049. Retrieved from http://www.m.elewa.org/JAPS

MEA. (2005). Ecosystems and Human WellBeing: Synthesis. Island Press, Washington, DC.

Montagne, P. (1997). Les marchés ruraux de bois-énergie au Niger: outils de développement rural local.

Montagne, P., Housseini, M., \& Sanda, L. O. (1997). Les marchés ruraux de bois-énergie au Niger: le mode de développement. Fonctionnement et gestion des écosystèmes forestiers contractés sahéliens. J. Libbey Eurotext, Paris, France, 169-184.

Müller, J. (2013). Floristic and structural pattern and current distribution of tiger bush vegetation in Burkina Faso (West Africa), assessed by means of belt transects and spatial analysis. Applied Ecology And Environmental Research, 11(2), 153-171.

Ngom, D., Fall, T., Sarr, O., Diatta, S., \& Akpo, L. E. (2013). Caractéristiques écologiques du peuplement ligneux de la réserve de biosphère du Ferlo (Nord Sénégal). Journal of Applied Biosciences, 65, 5008-5023.

Nicholson, E., \& Grist, J. P. (2001). A conceptual model for understanding rainfall variability in the West African Sahel on interannual and interdecadal timescales. Int. J. Climatol., 21, 1733-1757. https://doi.org/10.1002/ joc. 648

Oesterheld, M., \& Sala O. E. (1990). Grazing effect upon seedling establishment: the role of seed and safe-site availability. Journal of Vegetation Science, 1, 353-358.

Okiror, P., Chono, J., Nyamukuru, A., Lwanga, J. S., Sasira, P., \& Diog, P. (2012). Variation in Woody Species Abundance and Distribution in and around Kibale National Park, Uganda. International Scholarly Research Network. https://doi.org/10.5402/2012/490461

Ozer, P., Hountondji, Y. C., Niang, A. J., Karimoune, S., Manzo, O. L., \& Salmon, M. (2010). Désertification au Sahel : Historique et Perspectives. BSGLg, 54, 69-84.

Rabiou, H., Diouf, A., Bationo, B. A., Mahamane, A., Segla, K. N., Radji, R., ... \& Saadou, M. (2015). Structure démographique de peuplement naturel et répartition spatiale des plantules de Pterocarpus erinaceus Poir. dans la forê. International Journal of Biological and Chemical Sciences, 9(1), 69-81. Retrieved from http://ajol.info/index.php/ijbc

Saley, K., Allah, M. Z., Morou, B., Mahamane, A., \& Saadou, M. (2012). Land Cover/Use Dynamics and Vegetation Characteristics in the Rural District of Simiri (Tillabery Region, Niger). In The Functioning of Ecosystems. InTech. Retrieved from http://www.intechopen.com/books/the-functioning-of-ecosystems/ spatial-and-temporal-dynamics-of-the-falkipond-ecosystem-in-the-region-of-zinder-niger

Savadogo, O., Ouattara, K., Pare, S., Ouedraogo, I., Sawadogo-Kaboré, S., Barron, J., \& Zombre, N. (2016). Structure, composition spécifique et diversité des ligneux dans deux zones contrastées en zone Sahélienne du Burkina Faso. [VertigO] La revue électronique en sciences de l'environnement, 16(1). Retrieved from http://vertigo.revues.org/17282

Schmidt, M., Kreft, H., Thiombiano, A., \& Zizka, G. (2005). Herbarium collections and field data-based plant diversity maps for Burkina Faso. Diversity and Distributions, 11(6), 509-516.

Van Laar, A., \& Akc, A. A. (2007). Forest Mensuration. Springer, the Netherlands.

Von Maydell, H. J. (1990). Arbres et arbustes du sahel. Leurs caractéristiques et leurs utilisations. Deutche-Gesellschaft technische Zuzammenarbeit GTZ.

Yeo, J. J. (2005). Effects of grazing exclusion on rangeland vegetation and soils, East Central Idaho. Western North American Naturalist, 65(1), 91-102.

\section{Copyrights}

Copyright for this article is retained by the author(s), with first publication rights granted to the journal.

This is an open-access article distributed under the terms and conditions of the Creative Commons Attribution license (http://creativecommons.org/licenses/by/4.0/). 